\title{
COMPUTATIONAL AND EXPERIMENTAL DETERMINATION OF ENERGY LOSS OF THE OPERATING FLUID IN THE INTAKE SYSTEM OF THE AUTOMOBILE PISTON PNEUMATIC ENGINE USING THE EXERGY METHOD
}

\section{A. Voronkov, A. Charchenko, I. Nikitchenko, Ye. Novikova, E. Teslenko, A. Nazarov, Kharkiv Nathional Automobile Highway University}

\begin{abstract}
The application exergy method of the thermodynamic analysis for determining the energy loss of the operating fluid in the intake system of the automobile piston pneumatic engine using experimental data of its engine test rigs has been considered. The analysis of the performed exergy calculational and experimental research on the evaluation of energy loss in the intake system of the engine for current modes of its operation has been presented. The sample of a piston pneumatic engine for a combined automobile power unit created at the ICE Department of KhNAHU requires further improving and developing especially such components and systems as those connected to the burn process. A compressed air intake system is one of them. Compressed air is not only some working fluid for a pneumatic engine but the energy source for its intake system. The energy loss factor like reliability and durability is referred to the performance and efficiency factors. The object of the study is a pneumatic engine created by converting a gasoline four-cylinder four-stroke ICE at the ICE Department of KhNAHU. The experimental research was carried out by laboratory engine test rigs of the pneumatic engine with speed characterization provided that two thermodynamic parameters of compressed air at the intake were kept constant for each characteristic: pressure $p_{s}=$ idem and temperature $T_{s}=293 \mathrm{~K}$. In each test mode all external parameters of the pneumatic engine were recorded and indicator diagrams of the first cylinder were taken. Each speed characteristic consisted of 6-8 modes $p_{s}=i d e m$ and $T_{s}=293 \mathrm{~K}=$ idem with changing the rotational rate of the crankshaft $n, \mathrm{rpm}$, from minimally stable (about $n=200 \mathrm{rpm}$ ) to maximum possible $n=1000 \pm 50 \mathrm{rpm}$ It should be noted that there is an operating fluid pressure drop in the intake system chamber due to available inconvertibilities: throttling in the test port, hydraulic loss along the intake port as a result of fluid friction, swirls and other gas-dynamic phenomena. The exergy loss of the operating fluid

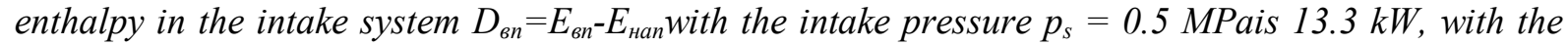
intake pressure $p_{s}=0.7 \mathrm{MPa}$ is $15.0 \mathrm{~kW}$, with the intake pressure $p_{s}=0.9 \mathrm{MPa}$ is $16.9 \mathrm{~kW}$, with the intake pressure $p_{s}=1.1 \mathrm{MPa}$ is $19.7 \mathrm{~kW}$.
\end{abstract}

Key words: piston pneumatic engine, intake system, energy loss, enthalpy exergy, maximum efficient power modes.

\section{Introduction}

The sample of a piston pneumatic engine for a combined automobile power unit created at the ICE Department of KhNAHU requires further improving and developing especially such components and systems as those connected to the burn process. A compressed air intake system is one of them. Compressed air is not only some working fluid for a pneumatic engine but the energy source for its intake system. The energy loss factor like reliability and durability is referred to the performance and efficiency factors.

The method of determining the energy loss of the compressed air in the intake system of the pneumatic engine using the experimental data
[1] and well-known exergy method [2, 3] has been considered in the paper.

\section{Purpose and Tasks}

The purpose of this computational and experimental study is to develop a technique for applying the well-known exergy method to determine the energy loss of the operating fluid of the piston pneumatic engine in the intake system and the energy loss of operating fluid (compressed air) as its enthalpy exergy loss in the intake system of the piston pneumatic fourcylinder engine with intake operating pressures $p_{s}=0.5-1.1 \mathrm{MPa}$ at the modes of the maximum possible efficient power $N_{\mathrm{e}}{ }^{\max }$ at given pressure levels $p_{s}$ according to speed characteristics 
$p_{s}=$ idem with in take constant temperature $T_{s}=293 \mathrm{~K}$.

\section{Analysis of Publications}

Nowadays there are many publications devoted to the fundamentals of the exergy analysis and its application in various fields of technology. Last decade of the twentieth century the work on creation of a mathematical apparatus of exergy analysis in solving optimization problems in the field of improving currentequipment and designing new equipment and technologywas completed. The fundamentals of exergy analysis are mostly generalized and fully described in the works of V. M. Brodyansky [2], G. N. Kostenko [3], A. R. Kotin [4], G. D. Rem [5]. The issues of the exergy method application in the field of heat engineering are studied by A. I. Andryushchenko [6 and others].

Almost all the studies on the exergy method published since 1964 are referred to the exergy applications in heat engineering, chemical technology, metallurgy, cryogenic engineering and economics. The discussions about the necessity of this section in thermodynamics and correctness of its main principles were left in past. In the $21^{\text {st }}$ century the exergy method got known to many specialists of various fields of technology. They considered it as a convenient tool for solving their specific tasks. The main advantages of the exergy method of thermodynamic analysis are its simplicity and universality [2]. It is possible to determine both absolute and relative values of energy loss due to inconvertibilities for any process or its part using the exergy balance.

So in the recently published work [7] the simplicity and accuracy of determining the energy loss of the operating fluid in case of its inconvertible leakages using the exergy method were presented. This paper shows determiningthe dependence of the exergy characteristic - enthalpy exergy loss due to external conditions: pressure and temperature of the supplied compressed air at the intakeof the power unit $p_{s}$ and $T_{s}$ were found using experimental data and theoretical dependences between the burn process parameters.

\section{Object of Study}

The object of the study is a piston pneumatic engine with specifications presented in Table 1 . The considered pneumatic engine was created at the ICE Department of KhNAHU by converting a gasoline four-cylinder four-stroke ICE. The experience of this conversion is described in detail in [1].

In accordance with the aboveformulated purposethe specific object of the study in the experiment and calculations is the intake system of the pneumatic engineprototype sample. Each cylinder of the engine has the same intake system through which the process of filling the cylinders with the incoming charge of compressed air is carried out.

Table 1 - Specificationsof a piston pneumatic engine with spool-type air distribution -prototype sample designed and created at the ICE Department of KhNAHU in 2008

\begin{tabular}{|l|c|c|c|}
\hline \multicolumn{1}{|c|}{ Parameter } & Notation & Dimensions & Numeric value \\
\hline Cylinder diameter & $D$ & $\mathrm{~mm}$ & 76 \\
\hline Piston stroke & $S$ & $\mathrm{~mm}$ & 66 \\
\hline Number of cylinders & $Z$ & - & 4 \\
\hline Included angle of cylinder block & $\gamma$ & degree & 90 \\
\hline Cylinder displacement & $V_{h}$ & $\mathrm{dm}^{3}$ & 0.2994 \\
\hline Volume ofclearance space & $V_{0}$ & $\mathrm{dm}^{3}$ & 0.280 \\
\hline Relativeclearance volume $E_{0}=V_{0} / V_{h}$ & $E_{0}$ & - & 0.935 \\
\hline Filling volume & $V_{1}$ & $\mathrm{dm}^{3}$ & 0.0862 \\
\hline Filling rate $E_{1}=V_{1} / V_{h}$ & $E_{1}$ & - & 0.288 \\
\hline Volume of reverse compression start & $V_{3}$ & $\mathrm{dm}^{3}$ & 0.147 \\
\hline Degree of reverse compression $\mathrm{E}_{3}=\mathrm{V}_{3} / \mathrm{V}_{\mathrm{h}}$ & $E_{3}$ & - & 0.491 \\
\hline Fullflowareaattheintakeline & $f_{s}^{\max }$ & $\mathrm{m}^{2} \cdot 10^{4}$ & 3.14 \\
\hline Fullflowareaattheexhaustline & $f_{\mathrm{T}}^{\max }$ & $\mathrm{m}^{2} \cdot 10^{4}$ & 3.14 \\
\hline Adiabatic exponent of dry air & $k$ & - & 1.40 \\
\hline Adiabatic exponent of humid air, relative humidity $\varphi=100 \%[9]$ & $k_{p}$ & - & 1.32 \\
\hline
\end{tabular}

This process is not adjustable. It is performed by a structurally specified period of filling the cylinder with the incoming charge of compressed air. The process of filling lasts up to 58 degrees of crankshaft turn: three degrees before- top dead centre (TDC) and 55 degrees after TDC.

The cylinder in take system includesan in take port of circular cross-section with a diameter of $20 \mathrm{~mm}$ and a length of $800 \mathrm{~mm}$, two 
test ports of the same cross-section: the first is on the outer cylindrical rotor surface of the spool-type air distributor and the second is on the inner cylindrical stator surface at the beginning of the intake port. Test ports are partially or fully matched during the filling. Their combined flow area varies from zero to a maximum that is equal to the area of an open port.

The volume of the internal chamber of the intake system alongside with the object above the piston space at the top dead centre is socalled dead volume that increases the flow density of compressed air $\mathrm{g}_{\mathrm{e}}, \mathrm{kg} /(\mathrm{kW} / \mathrm{h})$.

\section{Experimental Techniques}

The experimental study was carried out by laboratory engine test rigs of the pneumatic engine with speed characterization provided that two thermodynamic parameters of compressed air at the intake were kept constant for each characteristic: pressure $\mathrm{p}_{\mathrm{s}}=$ idem and temperature $T_{\mathrm{s}}=293 \mathrm{~K}$. In each test mode all external parameters of the pneumatic engine were recorded and indicator diagrams of the first cylinder were taken. Each speed characteristic consisted of 6-8 modes $\mathrm{p}_{\mathrm{s}}=$ idem and $\mathrm{T}_{\mathrm{s}}=293 \mathrm{~K}$ = idem with changing the rotational rate of the crankshaft $\mathrm{n}, \mathrm{rpm}$, from minimally stable (about $\mathrm{n}=200 \mathrm{rpm}$ ) to maximum possible $\mathrm{n}=1000 \pm 50$ $\mathrm{rpm}$. The method of pneumatic engine testing to take the speed characteristics of the pneumatic engine is described in detail in [1].The whole experiment comprised four speed characteristics for intake pressures of the compressed air (being the subject of the greatest scientific and practical interest), $\mathrm{p}_{\mathrm{s}}=0.5 ; 0.7 ; 0.9$ and $1.1 \mathrm{MPa}$, at constant temperature $\mathrm{T}_{\mathrm{s}}=293 \mathrm{~K}$.

Then using the obtained experimental data we constructed the dependences graphs of the efficient power $\mathrm{N}_{\mathrm{e}}, \mathrm{kW}$, on the rotational speed of the shaftn, rpm and determined the maxima of the functions $\mathrm{N}_{\mathrm{e}}(\mathrm{n})$-the modes of the indicated power of the pneumatic engine for the corresponding pressure level $p_{s}$ at the temperature $T_{s}$, corresponding to the ambient temperature $\mathrm{T}_{\mathrm{o} . \mathrm{c}}=293 \mathrm{~K}$.

The operating fluid energy loss in the intake system of the pneumatic engine was determined only for these four modes $\mathrm{N}_{\mathrm{e}}{ }^{\max }$ mentioned above (being of exceptional interest).

\section{Results of the Computational and}

Experimental Study and Their Analysis Using the Exergy Method

The main results of this experimental and computational study are presented in Table 2 and fig. 1. They are the results of the second stage of the study, the starting points for which are the results of the first stage devoted to the determining the operating fluid energy loss at the very beginning of the working chamber of the pneumatic engine- in the spool-type air distributor due to leakage of incoming compressed air $D_{y m}, \mathrm{~kW}$ [7].

Thus the starting point for the second stage of the study is the level of exergy of the operating fluid enthalpy at the beginning of the intake process equal to the enthalpy exergy of $\mathrm{E}_{\mathrm{s}}, \mathrm{kW}$, supplied to the engine, minus the energy loss for leakage.

$$
E_{\mathrm{B \Pi}}=E_{\mathrm{s}}-D_{y m}, \mathrm{~kW} .
$$

After that we defined the level of exergy of the operating fluid enthalpy at the end of the intake, i.e. at the end of the filling process, $E_{\text {нап, }}$, $\mathrm{kW}$, that was dependant on the thermodynamic parameters of the air condition at that moment, primarily on its pressure $\mathrm{p}_{\text {нап }}$ and temperature $T_{\text {нап }}$.

It should be noted that there is an operating fluid pressure drop in the intake system chamber due to available inconvertibilities: throttling in the test port, hydraulic loss along the intake port as a result of fluid friction, swirls and other gasdynamic phenomena.

The analysis of the obtained indicator diagrams during the engine test rigs allowed to determine the cylinder pressure values while filling. Table 2 shows the pressure values in the working chamber at various levels of compressed air intake pressure $\mathrm{p}_{\mathrm{s}}$ for maximum power modes according to speed characteristics. The thermodynamic parameters (enthalpy and entropy) were determined according to the level of air pressure and temperatureusing tables [8]. The performance was calculated as the specific enthalpy exergy $e_{\text {нап, }}, \mathrm{kJ} / \mathrm{kg}$, and the mass for the gas flow $E_{\text {нап }}, \mathrm{kW}$.

It should be noted thatchangingtemperature of the operating fluid while filling provided that the compressed air is supplied into the engine at ambient temperature $T_{s}=T_{\text {o.c }}=293 \mathrm{~K}$ may be neglectedon the basis of little heat exchange with the environment due to the absence of temperature difference and extremely short filling process (milliseconds), absence of expansion and contraction processes, and present throttling process occurred with a constant gas enthalpycan cause as known [10] a Joule-Thompson effect not exceeding the temperature drop by more than $1 \mathrm{~K}$, i. e., within the accuracy of temperature measuring. 
All this allows us to calculate the exergy of the operating fluid enthalpy at the end of the filling process according to its pressurep and temperature $T_{\text {нап }}=T_{\text {о.c. }}=293 \mathrm{~K}$ taking into account known dependences[2 и 5]:

- specific exergy

$$
\mathrm{e}_{\text {нап }}=\left(h_{\text {нап }}-h_{\text {о.с. }}\right)-T_{\text {о.с. }}\left(S_{\text {нап }}-S_{\text {о.с }}\right), \mathrm{kJ} / \mathrm{kg}(
$$

- air flow at the end of the filling process

$$
E_{\text {нап }}=G_{\text {полез }} \cdot \mathrm{e}_{\text {нап }}, \mathrm{kW} \text {, }
$$

where $G_{\text {полез }}=G-G_{\text {уг }}, \mathrm{kg} / \mathrm{s}$ - mass second compressed airflowefficiently used; $G, \mathrm{~kg} / \mathrm{s}-$ compressed air flow supplied into the pneumatic engine; $G_{\text {ут }}, \mathrm{kg} / \mathrm{s}$-experimentally found mass flow of compressed air for leakage inthe given pneumatic engine, depending on its parameters at the intake; $h_{\text {нап }}, h_{\text {o.c., }} \mathrm{kJ} / \mathrm{kg}$-air specific enthalpy respectively for the given pressure $p_{\text {нап }}$ and temperature $T_{\text {нап, and for ambient }}$ parameters $p_{\text {o.c }}$ and $T_{\text {o.c }} ; T_{\text {o.c }}, \mathrm{K}-$ ambient temperature; $S_{\text {нап }}, S_{\text {ос..; }} \mathrm{kJ} /(\mathrm{kg} \mathrm{K})$-air specific entropy respectively in terms of $p_{\text {нап, }}, T_{\text {нап }}$ and in terms of $p_{\text {o.c }}$ and $T_{\text {o.c }}$

The exergy loss of the operating fluid enthalpy in the intake system is equal to the difference in its exergy levels at the beginning and at the end of the process

$$
D_{\text {вп }}=E_{\text {вп }}-E_{\text {нап, }}, \mathrm{KW} \text {. }
$$

Table 2 - Experimental data on the heat loss of the operating fluid in the intake system of the piston pneumatic

\begin{tabular}{|c|c|c|c|c|c|c|}
\hline \multirow{2}{*}{ NameofValue } & \multirow{2}{*}{$\begin{array}{l}\text { Nota- } \\
\text { tion }\end{array}$} & \multirow{2}{*}{$\begin{array}{l}\text { Dimen- } \\
\text { sion }\end{array}$} & \multicolumn{4}{|c|}{ Pressure $\mathrm{P}_{\mathrm{s}}, \mathrm{MPa}$} \\
\hline & & & 0.5 & 0.7 & 0.9 & 1.1 \\
\hline Supplied (spent) amount of compressed air & $G$ & $\mathrm{\kappa g} / \mathrm{s}$ & 0.0339 & 0.0656 & 0.1000 & 0.1583 \\
\hline \multirow{2}{*}{$\begin{array}{l}\text { Supplied (spent) thermal energy of the operating } \\
\text { fluid in the form of its enthalpy } H_{s}=G \cdot h_{s}\end{array}$} & \multirow[t]{2}{*}{$H_{s}$} & $\mathrm{\kappa W}$ & 9.91 & 19.17 & 29.17 & 46.08 \\
\hline & & $\%$ & 100 & 100 & 100 & 100 \\
\hline \multirow{2}{*}{$\begin{array}{l}\text { Supplied (spent) operative heat energy - } \\
\text { enthalpy energy }\end{array}$} & \multirow[t]{2}{*}{$\overline{E_{s}}$} & $\mathrm{KW}$ & 4.59 & 10.69 & 18.77 & 31.72 \\
\hline & & $\%$ of $E_{s}$ & 100 & 100 & 100 & 100 \\
\hline \multirow{2}{*}{$\begin{array}{l}\text { The content of non-operative heat - enthalpy } \\
\text { energy in the supplied heat (in the compressed } \\
\text { air enthalpy) }\end{array}$} & \multirow[t]{2}{*}{$B_{s}$} & кW & 5.32 & 8.48 & 10.36 & 14.36 \\
\hline & & $\%$ of $H_{s}$ & 53.7 & 44.2 & 35.5 & 31.2 \\
\hline \multicolumn{7}{|l|}{$G_{\text {полез }}=G-G_{\text {ут }}$} \\
\hline & 292.4 & 291.3 & 290.0 \\
\hline $\begin{array}{l}\text { The specific entropy of compressed air under } \\
\text { the conditions at the intake of the pneumatic } \\
\text { engine }\end{array}$ & $S_{s}$ & $\mathrm{KJ} / \mathrm{Kg} \cdot \mathrm{K}$ & 6.382 & 6.288 & 6.213 & 6.156 \\
\hline $\begin{array}{l}\text { Air specific enthalpy according to } \\
\text { environmental conditions }\end{array}$ & $h_{\text {o.c. }}$ & $\mathrm{\kappa J} / \mathrm{\kappa g}$ & 293.2 & 293.2 & 293.2 & 293.2 \\
\hline & $S_{\text {o.c. }}$ & $\mathrm{KJ} / \mathrm{Kg} \cdot \mathrm{K}$ & 6.847 & 6.847 & 6.847 & 6.847 \\
\hline $\begin{array}{l}\text { Specific exergy of air enthalpy under the terms } \\
\text { of pneumatic engine intake }\end{array}$ & $\mathrm{e}_{\mathrm{s}}$ & $\mathrm{\kappa J} / \mathrm{\kappa g}$ & 135.4 & 163.0 & 187.7 & 200.3 \\
\hline $\begin{array}{l}\text { The pressure in the working chamber at the end } \\
\text { of the filling process (intake) }\end{array}$ & $P_{\text {вп }}$ & МПа & 0.395 & 0.495 & 0.580 & 0.640 \\
\hline \multicolumn{7}{|l|}{ The specific exergy of the operating fluid } \\
\hline \multirow{2}{*}{$\begin{array}{l}\text { The exergy of the operating fluid enthalpy at the } \\
\text { beginning of the intake } E_{\mathrm{Bn}}=E_{s}-D_{y m}, \mathrm{KW}\end{array}$} & \multirow[t]{2}{*}{$E_{\text {вп }}$} & $\mathrm{KW}$ & 4.38 & 9.40 & 16.14 & 27.98 \\
\hline & & $\%$ of $E_{s}$ & 95.4 & 87.9 & 86.0 & 88.2 \\
\hline $\begin{array}{l}\text { The specific exergy of the operating fluid } \\
\text { enthalpy at the end of the filling process }\end{array}$ & $e_{\text {нап }}$ & $\mathrm{\kappa J} / \mathrm{\kappa g}$ & 116.5 & 135.3 & 150.7 & 155.6 \\
\hline \multirow{2}{*}{$\begin{array}{l}\text { The exergy of the operating fluid enthalpy at the } \\
\text { end of filling } E_{\text {нап }}=G_{\text {полез }} \cdot e_{\text {нап, }}, \mathrm{KW}\end{array}$} & \multirow[t]{2}{*}{$E_{\text {нап }}$} & $\mathrm{\kappa W}$ & 3.77 & 7.80 & 21.95 & 21.72 \\
\hline & & $\%$ of $E_{s}$ & 82.1 & 73.0 & 69.0 & 68.2 \\
\hline \multirow{2}{*}{$\begin{array}{l}\text { Exergy loss of the operating fluid enthalpy in } \\
\text { the intake system } D_{\mathrm{вп}}=E_{\text {вп }}-E_{\text {нап, }}, \mathrm{KW}\end{array}$} & \multirow[t]{2}{*}{$D_{\text {вп }}$} & KW & 13.3 & 15.0 & 16.9 & 19.7 \\
\hline & & $\%$ of $E_{s}$ & 116.5 & 135.3 & 150.7 & 155.6 \\
\hline
\end{tabular}
engine during its operation according to speed characteristics $p_{s}=$ idem and constant intaketemperature of compressed air $T_{s}=293 \mathrm{~K}$ at maximum power modes $N_{e}^{\max }$, according to [1] 


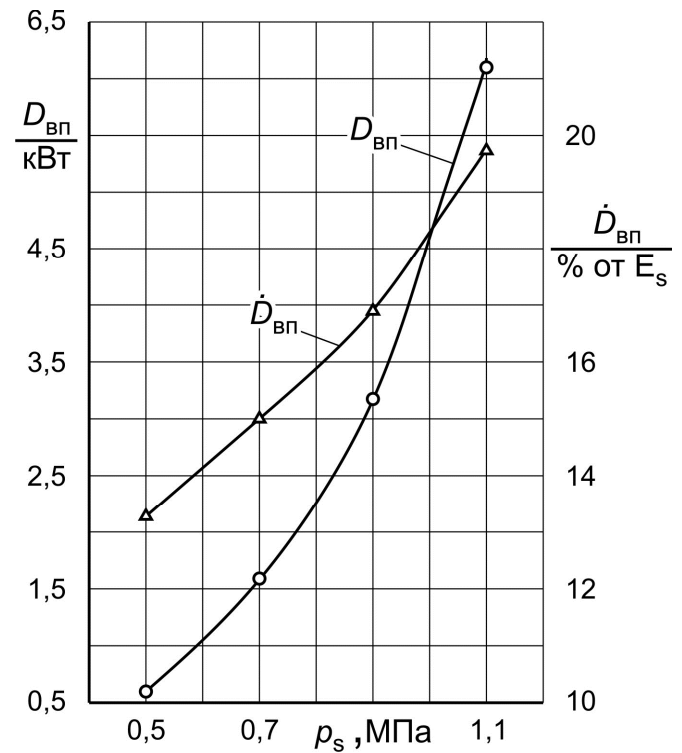

Fig.1. Diagrams of absolute $\mathrm{D}_{\mathrm{в}}, \mathrm{kW}$, and relative $D_{\text {вп }} \%$ changes from $E_{\mathrm{s}}$, exergy loss of the operating fluid enthalpy due to reducing gasdynamic loss of the pressure in the intake system during the filling while operating the pneumaticengine at maximum power $\mathrm{N}_{\mathrm{e}}{ }^{\max }$ with speed characteristics dependant on the level of pressure $\mathrm{p}_{\mathrm{s}}, \mathrm{MPa}$

Fig. 1 represents the increase of the energy loss of the operating fluid in the form of its enthalpy exergy loss in proportion to the increase of the supplied compressed air pressure at the engine intake $p_{s}$ not linearly, but by some increasing intensity. This is quite logical and is explained by the fact that with an increase in the pressure $p_{s}$ of the crankshaft rotational speed $n$, at which the maximum power $\mathrm{N}_{\mathrm{e}}$ is achieved, and shifted towards higher frequencies. Definitely this issue, first, 1 eads to increasing the hydraulic resistance in the intake and exhaust air ports.

\section{Conclusion}

A technique for applying the well-known exergy method to determine the energy loss of the operating fluid of the piston pneumatic engine in the intake system with intake operating pressures $p_{s}=0.5-1.1 \mathrm{MPa}$ at the modes of the maximum possible efficient power $N_{\mathrm{e}}{ }^{\max }$ at given pressure levels $\mathrm{p}_{\mathrm{s}}$ according to speed characteristics $p_{s}=$ idem withintake constant temperature $\mathrm{T}_{\mathrm{s}}=293 \mathrm{~K}$ has been developed.

The scientific significance of this work is the development of a technique for applying the well-known exergy method to determining the energy loss of the operating fluid of the piston pneumatic engine in the intake system.
The practical and scientific significance of this work is the following: for a particular type of piston automobile pneumatic engine with a spool-type air distribution the level and patterns of changes in the energy loss of the operating fluid in the form of the enthalpy exergy loss in the intake system depending on the compressed air supplied pressure at the intake in the most important operating range of $p_{s}=0.5-1.1 \mathrm{MPa}$ at constant air temperature equal to ambient temperature $T_{s}=T_{\mathrm{o} . \mathrm{c}}=293 \mathrm{~K}$ have been determined.

The level of energy loss of the operating fluid (compressed air) in the form of its enthalpy exergy loss in the intake system of a fourcylinder piston pneumatic engine while its operating with various intake pressures are: with intake pressure $p_{s}=0.5 \mathrm{MPa}$ is $13.3 \mathrm{~kW}$ $\left(116.5 \%\right.$ of $\left.E_{s}\right)$, with intake pressure $p_{s}=$ $0.7 \mathrm{MPa}$ is $15.0 \mathrm{~kW}\left(135.3 \%\right.$ of $\left.E_{s}\right)$, with intake pressure $p_{s}=0.9 \mathrm{MPa}$ is $16.9 \mathrm{~kW}(150.7 \%$ of $E_{s}$ ), with intake pressure $p_{s}=1.1 \mathrm{MPa}$ is $19.7 \mathrm{~kW}$ $\left(155.6 \%\right.$ of $\left.E_{s}\right)$.

\section{References}

1. Воронков А.И., Никитченко И.Н. Рабочий процесс автомобильного пневмодвигателя: монография. - Х.: ХНАДУ, 2015. - 200 с.

2. Бродянский В.М., Фратшер В., Михалек К., Бродянский В.М. Эксергетический метод и его приложения / Под. ред. В.М.Бродянского. М.: Энергоатомиздат, 1988. - 288 с.

3. Костенко Г.Н. Эксергетический анализ тепловых процессов и установок: конспект лекций. - Одесса (ОПИ), 1964.

4. Котин А.О. О физической сущности понятия эксергия // Известия вузов, Энергетика, 1965. № 7. C. 49-57.

5. Бэр Г.Д. Техническая термодинамика: теоретические основы и технические приложения / Под ред. В.М. Бродянского и Г.Н. Костенко. М.: Мир, 1977. -519 c.

6. Андрющенко А.И. Вопросы термодинамической теории теплофикационных установок / А.И.Андрющенко. - М.: МЭИ, 1955.

7. Воронков А.И. Определение потерь эксергии энтальпии рабочего тела в золотниковом воздухораспределителе автомобильного поршневого пневмодвигателя.

8. Варгафтик Н.Б. Справочник по теплофизическим свойствам газов и жидкостей. - М.: Энергоиздат, 1972. - 636 с.

9. Борисенко К.С. Пневматические двигатели горных машин. - М.: Углетехиздат, 1958. $205 \mathrm{c}$.

10. Алабовский А.Н., Недужий И. Техническая термодинамика и теплопередача. - К.: Вища шк. 1990. -255 c. 


\section{References}

1. Voronkov, A.I., Nikitchenko, I.N. (2015). Rabochiy protsess avtomobil'nogo pnevmodvigatelya [The burn process of the automobile pneumatic engine]: monografiya. Kh.: KhNADU, 200 [in Russian].

2. Brodyanskiy V.M., Fratsher V., Mikhalek K. (1988). Eksergeticheskiy metod i ego prilozheniya [Exergy method and its applications] Pod. red. V.M. Brodyanskogo. Moscow: Energoatomizdat, 288 [in Russian].

3. Kostenko G.N. (1964). Eksergeticheskiy analiz teplovykh protsessov i ustanovok [Exergy analysis of thermal processes and units]. Konspekt lektsiy. Odessa (OPI) [in Russian].

4. Kotin A.O. (1965). O fizicheskoy sushchnosti pon-yatiya eksergiya [On the physical essence of the exergy concept]. Izvestiya vuzov, Energetika, 7, 49-57 [in Russian].

5. Ber G.D. (1977). Tekhnicheskaya termodinamika: teoreticheskie osnovy i tekhnicheskie prilozheniya [Technical thermodynamics: theoretical fundamentals and technical applications]. Pod red. V.M. Brodyanskogo i G.N. Kostenko. Moscow: Mir. 519 [in Russian].

6. Andryushchenko A.I. (1955). Voprosy termodinamicheskoy teorii teplofikatsionnykh ustanovok [Issues of thermodynamic theory of heat installations]. Moscow: MEI [in Russian].

7. Voronkov A.I. Opredelenie poter' eksergii ental'pii rabochego tela $\mathrm{v}$ zolotnikovom vozdukhoraspredelitele avtomobil'nogo porshnevogo pnevmodvigatelya [Determination of exergy loss of the operating fluid enthalpy in the spool-type air distributor of the automobile piston pneumatic engine].

8. Vargaftik N.B. (1972). Spravochnik po teplofizicheskim svoystvam gazov i zhidkostey [Handbook of thermophysical properties of gases and liquids]. Moscow: Energoizdat, 636 [in Russian].

9 Borisenko K.S. (1958). Pnevmaticheskie dvigateli gornykh mashin [Pneumatic engines of mining machines]. Moscow: Ugletekhizdat, 205 [in Russian].

10. Alabovskiy A.N., Neduzhiy I. (1990). Tekhnicheskaya termodi $\neg$ namika i teploperedacha [Technical thermodynamics and heat transfer] Kijv: Vishcha shk., 255 [in Russian].

Voronkov Oleksandr Ivanovych, D.Sci., Associate Professor of Internal Combustion Engines Department, +380505830045, rio@khadi.kharkov.ua

Charchenko Anatolij Ivanovych, Associate Professor of Internal Combustion Engines Department, +38093549435, rio@khadi.kharkov.ua

Nikitchenko Igor Mykolayovich, PhD., Associate Professor of Internal Combustion Engines Department, +380993116110, nik@khadi.kharkov.ua
Novikova Yevgenia Borysivna, PhD., Associate Professor of Foreign Languages Department, +380958297372, rio@khadi.kharkov.ua

Teslenko Eduard Viktorovich, Post-Graduate of Internal Combustion Engines Department, +380678538385, rio@khadi.kharkov.ua

Nazarov Artem Oleksandrovych, Post-Graduate of Internal Combustion Engines Department, +380996537401, rio@khadi.kharkov.ua

Kharkiv National Automobile and Highway University, 61002, Ukraine, Kharkiv, Yaroslav Mudryi st., 25.

Розрахунково-експериментальне визначення втрат енергії робочого тіла в системі впуску автомобільного поршневого пневмодвигуна 3 використанням ексергетичного методу

Анотація. Розглянуто методику додатка эксергетичного методу термодинамічного аналізу для визначення втрат енергії робочого тіла в системі впуску автомобільного поршневого пневмодвигуна 3 використанням експериментальних даних його стендових моторних випробувань. Викладено аналіз виконаного ексергетичного розрахунково-експериментального дослідження 3 оцінки величин енерговтрат у системі впуску двигуна для актуальних режимів його роботи.

Створений на кафедрі ДВЗ ХНАДУ для комбінованої автомобільної силової установки зразок поршневого пневмодвигуна має потребу в удосконалюванні й доводці, особливо вузлів і систем, пов'язаних зі здійсненням робочого процесу. Однією $з$ таких систем є система впуску стисненого повітря. Для пневмодвигуна стиснене повітря є не тільки робочим тілом, але й енергоносієм для його системи впуску. До показників працездатності й ефективності, крім надійності й довговічності ставиться й показник рівня енергетичних втрат.

Об'єктом дослідження є розглянутий пневмодвигун, створений на кафедрі ДВЗ ХНАДУ шляхом конвертації бензинового чотирициліндрового чотиритактного ДВЗ.

Експериментальне дослідження проводилося шляхом лабораторних стендових моторних випробувань пневмодвигуна зі зняттям швидкісних характеристик за умови підтримки незмінних для кожної характеристики двох термодинамічних параметрів стисненого повітря на вході: тиску $\mathrm{p}_{\mathrm{s}}=$ idem i температури $T_{s}=293 \mathrm{~K}$. На кожному режимі випробувань реєструвалися всі зовнішні параметри роботи пневмодвигуна й знімалися індикаторні діаграми першого циліндра. Кожна швидкісна характеристика складалася із шестивосьми режимів $p_{s}=$ idem i $T_{s}=293 \mathrm{~K}=$ idem зі зміною частоти обертання колінчастого вала $n$, об/хв, від мінімально стійких (близько $n=200$ об/хв) до максимально можливих $n=1000 \pm 50$ об/хв. 
Слід зазначити, що в порожнині системи впуску відбувається падіння тиску робочого тіла внаслідок незворотних процесів: дроселювання в контрольному отворі, гідравлічних втрат по довжині впускного каналу внаслідок тертя газу об стінки, завихрень й інших газодинамічних явищ. Втрати ексергії ентальпії робочого тіла в системі впуску $D_{\text {вп }}=E_{\text {вп }}-E_{\text {нап }}$ становлять для тиску на впуску $p_{s}=0,5 \mathrm{MПа}-13,3$ кВт, для тиску на впуску $p_{s}=0,7 \mathrm{MПа}-15,0$ кВТ для тиску на впуску $p_{s}=$ $0,9 \mathrm{MПа} \mathrm{-} \mathrm{16,9} \mathrm{кВТ} \mathrm{,} \mathrm{для} \mathrm{тиску} \mathrm{на} \mathrm{впуску} p_{s}=$ 1,1 МПа - 19,7 кВт.

Ключові слова: поршневий пневмодвигун, система впуску, енергетичні втрати, ексергія ентальпії, режими максимальної ефективної потужності.

О. І. Воронков, проф., д.т.н., А.И. Харченко, доц., к.т.н., І. М. Нікітченко, доц., к.т.н., С. Б. Новикова, доц., к.ф.н., Е. В. Тесленко, аспірант, А. О. Назаров, аспірант, ХНАДУ

Расчетно-экспериментальное определение потерь энергии рабочего тела в системе впуска автомобильного поршневого пневмодвигателя с использованием эксергетического метода

Аннотация. Рассмотрена методика приложения эксергетического метода термодинамического анализа для определения потерь энергии рабочего тела в системе впуска автомобильного поршневого пневмодвигателя с использованием экспериментальных данных его стендовых моторных испытаний. Изложен анализ выполненного эксергетического расчетно-экспериментального исследования по оценке величин энергопотерь в системе впуска двигателя для актуальных режимов его работы.

Созданный на кафедре ДВС ХНАДУ для комбинированной автомобильной силовой установки образец поршневого пневмодвигателя нуждается в совершенствовании и доводке, особенно узлов и систем, связанных с осуществлением рабочего процесса. Одной из таких систем является система впуска сжатого воздуха. Для пневмодигателя сжатый воздух является не только рабочим телом, но и энергоносителем для его системы впуска. К показателям работоспособности и эффективно- сти, кроме надежности и долговечности относится и показатель уровня энергетических потерь.

Объектом исследования рассматриваемый пневмодвигатель, созданный на кафедре ДВС ХНАДУ путем конвертации бензинового четырехцилиндрового четырехтактного ДВС.

Экспериментальное исследование проводилось путем лабораторных стендовых моторных испытаний пневмодвигателя со снятием скоростных характеристик при условии поддержания неизменных для каждой характеристики двух термодинамических параметров сжатого воздуха на входе: давления $\mathrm{p}_{\mathrm{s}}=$ idem и температуры $T_{s}=293$ К. На каждом режиме испытаний регистрировались все внешние параметры работы пневмодвигателя и снимались индикаторные диаграммы первого цилиндра. Каждая скоростная характеристика состояла из шести-восьми режимов $p_{s}=$ idem и $T_{s}=293 \mathrm{~K}=$ idem с изменением частоты вращения коленчатого вала n, об/мин, от минимально устойчивых (около $n=200$ об/мин) до максимально возможных $n=1000 \pm 50$ об/мин.

Следует отметить, что в полости системы впуска происходит падение давления рабочего тела вследствие имеющих место необратимостей: дросселирования в контрольном отверстии, гидравлических потерь по длине впускного канала в результате трения газа о стенки, завихрений и прочих газодинамических явлений. Потери эксергии энтальпии рабочего тела в системе впуска $D_{\text {вп }}=E_{\text {вп }}-E_{\text {нап }}$ составляют для давления на впуске $p_{s}=0,5 \mathrm{MПа}-13,3$ кВТ, для давления на впуске $p_{s}=0,7 \mathrm{MПа}-15,0$ кВт, для давления на впуске $p_{s}=0,9 \mathrm{MПа}-16,9$ кВт, для давления на впуске $p_{s}=1,1 \mathrm{MПа}-19,7$ кВТ.

Ключевые слова: поршневой пневмодвигатель, система впуска, энергетические потери, эксергия энтальпии, режимы максимальной эффективной мощности.

А. И. Воронков, проф., д.т.н., А.И. Харченко, доц., к.т.Н., И. Н. Никитченко, доц., к.Т.н., Е. Б. Новикова, доц., к.ф.н., Э. В. Тесленко, аспирант, А. А. Назаров, аспирант, ХНАДУ 